https://doi.org/10.48009/2_iis_2014_77-88

Issues in Information Systems

Volume 15, Issue II, pp. 77-88, 2014

\title{
RESULTS OF ENVIRONMENTAL SCANNING APPLIED TO THE DESIGN OF A DEER MANAGEMENT DECISION SUPPORT SYSTEM (DSS) FOR THE UNITED STATES AND CALIFORNIA
}

\author{
G. Kent Webb, San Jose State University, g.webb@sjsu.edu
}

\begin{abstract}
Using freely available internet search tools for environmental scanning, information related to deer management was collected, categorized, and evaluated with the goal of providing public decision support. Key issues raised in the public debate discovered by the search are addressed with relevant information formatted as output for a decision support system - dashboard elements. A graph addresses contradictory reports about the current direction of the deer population; the trend since 2006 appears to be down. Another graph illustrates the approximate longterm population trend; the current U.S. white-tailed deer population is about the same as in 1500. A table summarizes profiles of state deer issues and strategies. Only eleven states are trying to reduce their deer population. A graph illustrates the rise and fall of the California population, the most dramatic population decline in the U.S. over the past 100 years. Hunting pressure and herd demographic management are found to be related to the decline, making these candidate variables for attention in the decision support system. This case application is designed to illustrate methods the author has learned in creating a variety of decision support applications for technology companies.
\end{abstract}

Keywords: Environmental Scanning, Internet Search, Decision Support Systems (DSS), Deer Management

\section{INTRODUCTION}

Many organizations, people, and animals have developed systems for scanning their environment to assess risks and rewards. Comparative advantages differ: sensitive noses for deer, advanced computer systems for the National Security Agency. Although there is extensive research on environmental scanning in the information systems literature, there are few documented applications [14]. As a project to build a public decision support system (DSS) for deer management, the internet has been scanned on a daily basis for four years to collect, categorize, and analyze data and information related to deer management. One goal is to identify important issues and to provide convenient access to information that can be used for decision support. Another goal is to use the combined expertise collected from the environmental scanning to identify variables and data that will improve a statistical deer population model, a more formal element of the decision support system that is under development. The approach reflects classical characteristics of decision support systems: "they attempt to combine the use of models or analytic techniques with traditional data access and retrieval functions [23]." The author has 30 years of high-tech industry experience producing decision support where the results are often proprietary. Methods developed from this experience are applied in this case to a public issue where all results are freely publishable.

Deer populations are typically managed by state and local governments using some varying degree of public input. The title of a famous book about the process in Pennsylvania, "Deer Wars" [10] gives a sense of the levels of interest among some of the stakeholders in the decision process. Information on the internet and in the media, with varying levels of reliability, will affect the decision making. Recent, significant, related information events include a fall, 2013, cover of Time magazine featuring a doe, a female deer, in a bucolic forest scene with the words "America's Pest" written in red. The article in its title argues "It is time to cull the herd" and states that "Thirty million strong and growing, the population of white-tailed deer in the U.S. is larger today than it was when Columbus sailed the ocean blue, according to National Wildlife Research Center scientist Kurt VerCauteren [8].” At about the same time, the San Francisco Examiner reported on the 80 percent decline in the California deer population over the past 50 years and discussed some of the factors associated with the decline, issues currently under study at the University of California, Davis [24].

A few months later, a deer expert in Connecticut reported that the population had plunged in recent years as a result of increased predation from coyotes and bobcats [11]. At about the same time, the Wall Street Journal reported deer populations were soaring from Long Island to California [4]. During the deer hunting season of 2013-14, deer managers in Illinois, Maine, North Dakota, Iowa, Minnesota and Wyoming and other states were explaining to the 
media why the deer population in their states was declining. Following a review of some of the environmental scanning literature in the next section, this paper presents figures and tables that are key information outputs for the deer management decision support system - elements of the system dash board.

\section{Environmental Scanning}

Wei and Lee [28] define environmental scanning as "the acquisition and use of information about events, trends, and relationships in an organization's external environment." In his book Information Management for the Intelligent Organization: The Art of Scanning the Environment, Choo [5] concludes from a summary of literature "Decision makers ... must identify problems, search for solutions ... must actively search for the required information." In a recent overview of related research, Rohrbeck and Bade [20] summarize over 250 articles and call for "a stronger linkage to adjacent research." Welter and others [29] report that "As companies' environment is becoming increasingly volatile, scanning systems gain in importance." Abebe [1] concludes from an analysis of 90 manufacturing companies that "Environmental scanning is considered as one of the critical ingredients in the strategic formulation process." Palomino and others [17] try to "optimize the collection of Web-based information" to assist decision makers, an approach similar to this deer management project. Babatunde and Adebisi [2] conducted an empirical study that concludes, "the use of strategic environmental scanning in evaluating environmental forces (opportunities and threats) helps in seizing the opportunities and avoiding threats and it leads to organizational profitability." Through a series of executive interviews, Fabbe-Costes [9] concludes that environmental scanning can be used to design sustainable business supply chains.

\section{RESEARCH METHODOLOGY}

A daily internet search, restricted to the previous 24 hours using both Google Alerts and Microsoft Bing, has been used to collect text and data related to deer management issues over the past several years. This approach allows for the capture of information that would be difficult to find using a single, intensive search process. Information sometimes drops off the internet in a few months. Another problem is that Google Search, for example, typically provides access to less than 1,000 of the millions of results it reports as found at the top of the page. Much of the information that shows up in a daily search will quickly drop so low in the Google page rank that it could only be found by using very specific search terms. A searcher would have to know the specific terms to use in order to find the information, or try by using many different search term combinations.

Google Alerts provides the option of restricting the search to a specific time range and then reporting the results to the user by email. In this case, in order to perform the most thorough search, the time frame was restricted to the minimum, the previous 24 hours, and the resulting email reports were evaluated manually each day. Google Alerts also provides the user with the option of identifying retrieved search items as "irrelevant." By flagging results as irrelevant, the proportion of relevant searches is improved. Although manual evaluation of search results is somewhat time consuming, the researcher becomes acquainted with current issues by performing the evaluations. This learning process has been helpful in educating the researcher about trends and issues in the topic under investigation. More recently, a daily Bing search has been added to reduce the chances that information popping up on the internet will go unnoticed. Bing also provides the option of restricting search to new information appearing in the past 24 hours. Research on alternative approaches has revealed no better available method for conducting the environmental scan.

Search terms for the Google Alerts were determined by examining the volume of keywords searches using the Google Trends Tool, revealing that internet users often search for deer information by state, such as "Pennsylvania deer". Also, since deer are managed at the state level, the decision support system and the information from search was stored by state and then by topic. A few search terms have been added over time that the researcher has identified as important based on review of the search results. More generally, based on text and data collected from the internet during 2013 and early 2014, deer management issues getting significant attention, but accompanied by contradictory factual information, suggest questions one and two below for detailed investigation. The effort to find variables that should be included in a statistical deer population model suggests question three. This paper is organized to address the following three questions: 
$\mathrm{Q}_{1}$ : What is the direction of the trend for the U.S. deer population, up or down?

$\mathrm{Q}_{2}$ : How has the California deer population changed over time?

$\mathrm{Q}_{3}$ : What are the influences on the population trend for each state that should be included in building a decision support system?

\section{ANALYSIS AND ANSWERS TO QUESTIONS DISCOVERED IN THE ENVIRONMENTAL SCANNING}

The following sections present some answers to these questions based on information collected by the environmental scanning. The figures and tables used to answer each question have become dash board elements for the decision support system, a common information system approach to provide users with a quick summary of key information. This format is also commonly used in Executive Information Systems where the goal is to provide summary information to assist with strategy and can support a drill-down allowing for closer examination of specific data.

\section{$Q_{1}$ : What Is The Direction of the Trend for the U.S. Deer Population?}

Although accurate estimates of deer populations are difficult to achieve, most population estimates are based on hunting statistics: millions of hunters go out into the field each year following hunting rules that may be modified somewhat by government or private managers [13]. Population estimates are so controversial that the state of Wisconsin recently decided to do away with them; other states have made similar decisions. Nevertheless, management decisions often must address population issues and the phrase "deer population" is commonly used among internet users searching for information. Survey methods are also used to estimate population, including aerial, scat counts, and citizen scientists reporting their observations using the internet.

A relatively complete set of deer harvest data (deer killed by hunters) has been collected from each state over the period from 2006 to 2012. Data for the 2013 season is still incomplete. Some years for Florida and most years for Hawaii, with a very small deer population, were estimated. The harvest data from each state has a wide confidence level given the many problems of non-reporting. Some states rely on hunter surveys that have their own set of measurement problems. Given that, and other things being about equal, the deer harvest data will approximately track with the actual deer population. Figure 1 shows that the harvest data has declined over this period and this suggests also that the deer population has declined.

Figure 1. Total U.S. Reported Deer Harvest, 2006 to 2012

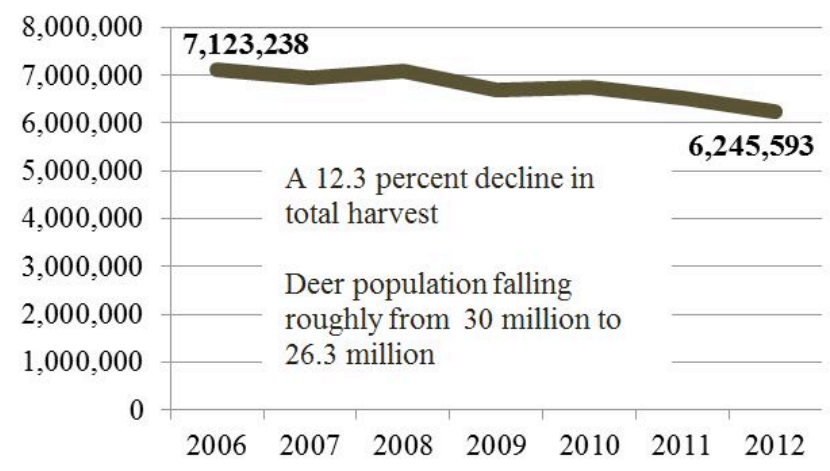




\section{Issues in Information Systems}

Volume 15, Issue II, pp. 77-88, 2014

Although no agency appears to be making a yearly estimate for the U.S. deer population, there are some estimates discovered from publically available sources. For example, "Although estimates of pre-European deer densities are imprecise, reliable accounts document a geographically widespread decline of deer populations in the late $19^{\text {th }}$ century [21]." VerCauteren [26] estimates that there were about 30 million white-tailed deer in pre-colonization area of the United States, around the year 1500, and that market hunting beginning in the 1600's started a downward decline in the deer population that accelerated into the early 1900's until few deer remained. Conservation efforts restored the population to about the same 30 million population level by 2000 . Although there may be overly abundant deer populations in some areas, deer populations are below historical averages in other areas.

The estimated U.S. white-tailed deer population, the most common deer, in Figure 2 is based on VerCauteren [26] (the researcher earlier referenced as a source for Time Magazine), McCabe [15], and the University of Florida [6]. The harvest data from Figure 1 is used to update the information for the 2006 to 2012 period, so a few years in the early 2000's are approximated. Of course, there is a wide error band on this estimate, illustrated to some extent by the wide line in Figure 2. Also, the harvest data used to estimate the 2006 to 2012 population trend includes nonwhite-tailed deer, about 10 percent of the total. A task for future research will be to separate these different deer populations for analysis. Non white-tailed deer generally reside west of the Mississippi river, were also hunted to very low levels during the early 1900's, but in many regions the recovery of these populations peaked in the 1960's and 1970's and has been on a decline since.

Figure 2. Estimated U.S. Whitetail Deer Population 1450 to 2012

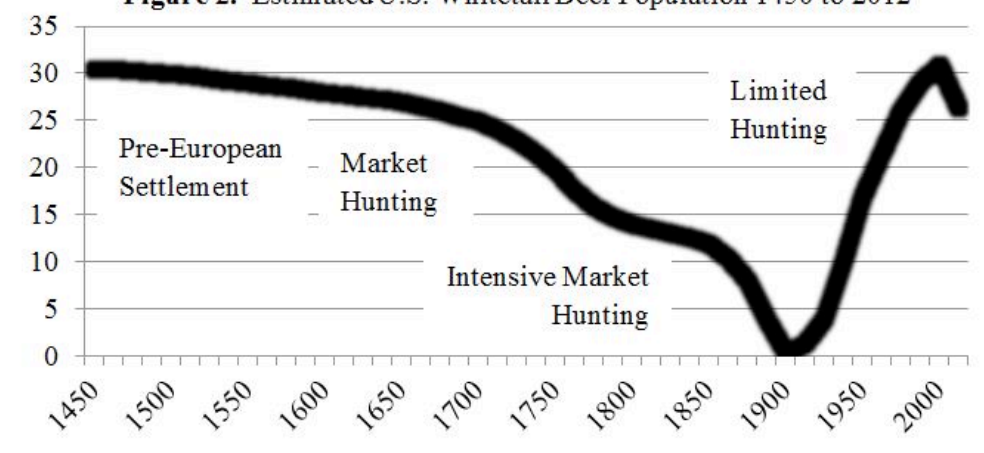


Answer to $Q_{l}$ : The recent total U.S. deer population trend appears to be down. The total U.S. white-tailed deer population has been estimated to be comparable to the pre-colonization population in about the year 1500 .

\section{$\mathrm{Q}_{2}$ : How has the California deer population changed over time?}

Although there is an historical population graph available from the California Department of Fish and Wildlife (CDFW) on its website, it hasn't been updated for about 20 years and the graph does not track with historical harvest data [27]. The department's more recent population estimates from 1990 to 2013 show a steep decline, but are not included in the graph on the website.

One method used by deer managers to control deer populations is to change the ratio of buck to doe hunting licenses issued. Killing a large proportion of does will reduce fawn production in the following year, putting downward pressure on the population. Since one buck can impregnate many does, reducing the proportion of does killed and targeting bucks is typically used as a strategy to increase herd growth. Each buck can impregnate more than one doe. During the rebuilding of deer herds during the middle of the 1900's, many states employed a bucks only harvest to enhance population growth.

California is unique in that it is the only state that has pursued essentially a bucks only harvest for almost every year since 1927 when deer hunting was resumed after a 10 year hiatus designed to protect the herd from over hunting. A common method for estimating deer populations is to use "harvest" data, the number of deer killed each year by hunters and then adjust the number for variations in sex and age. California's sex and age distributions have generally been about the same. This first pass at building a state population model for the decision support system relies on the reported kill (harvest) to population ratio based on the CDFW population analysis for 1990 to 2009 (data from 2010 to current are reported as preliminary by the department so are not used in the analysis). Also used is a very thorough study of the 1947 deer population conducted by William Longhurst and Aldo Leopold [12] who is considered by many to be the father of modern wildlife management. Note that the estimated kill to population ratio for 1947 reported in Table 1 is within the range of the modern period, 1990 to 2009, so it is assumed this ratio has been relatively constant over time. See Webb [27] for a more detailed discussion of this data.

Table 1. Historic Harvest (Kill) to Population Ratios

\begin{tabular}{|l|l|}
\hline $\begin{array}{l}\text { From recent 1990 to 2009 } \\
\text { CDFW Model* }\end{array}$ & $\begin{array}{l}\text { High: } 0.0456 \\
\text { Low: } 0.0273 \\
\text { Median: } 0.348\end{array}$ \\
\hline $\begin{array}{l}\text { From Longhurst Study of } 1947 \\
\text { Herd }\end{array}$ & 0.0422 \\
\hline $\begin{array}{l}\text { * Harvest numbers from } 2010 \text { to } 2013 \text { are reported as } \\
\text { preliminary by CDFW, so not used in this analysis }\end{array}$ \\
\hline
\end{tabular}

The population estimate in Figure 3 was created by taking a weighted average of eight population scenarios, each using one of the four historic kill to population ratios reported in Table 1 applied against the total buck harvest and also against the total deer harvest. In most cases, these harvest numbers are nearly identical. On average since 1927 the doe harvest in California has been less than three percent of the total population. In one year, 1956, the doe harvest was 31.2 percent of the population. As a result the population estimate for 1956 may be a little high and is one issue under consideration as model development moves forward. To smooth out year to year anomalies that may be related to hunting conditions or other time specific issues, the population estimate is a three year centered moving average. 
Figure 3. Deer Population Estimate for California, 1912 to 2012

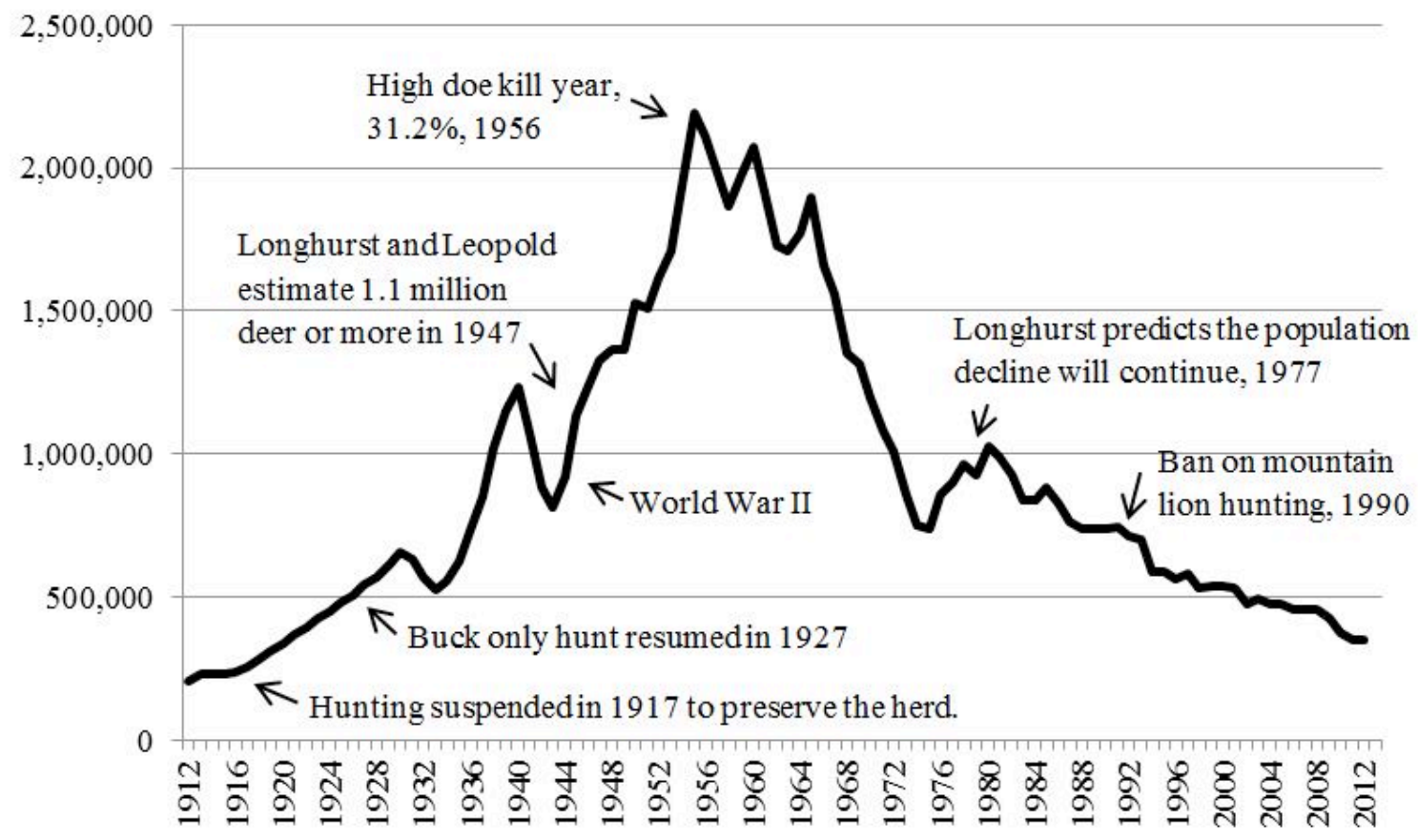

As Figure 3 illustrates, the current California deer population may have fallen back into the population range of 1917 to 1926 when deer hunting was suspended in order to preserve the herd. This was at a time when many families relied on the deer hunt as an important source of food. The graph identifies the 1990 ban on mountain lion hunting because the environmental scanning has identified this as a widely suspected contributing factor to the decline of the deer population and the topic of other current research.

The significant difference in the population pattern over the past 100 years in Figure 3 as compared to the whitetailed population illustrated in Figure 2 demonstrates an important issue regarding the development of deer management information: deer population status varies widely across the United States. A goal of the environmental scanning described in this paper is to collect and present this information to decision makers, and to use the information to build summary graphics such as Figure 3 that will assist in the public decision making process.

Answer to $Q_{2}$ : The California deer population rose from around 200,000 in 1912, peaking at about 2,000,000 around 1960, then falling to less than about 400,000 in 2012. Numbers are approximate. This population decline is the most severe of any state in the past 100 years.

\section{$\mathrm{Q}_{3}$ : What is the direction of and influences on the population trend for each state?}

Like many business organizations, state agencies compete for revenue. Resident and non-resident deer hunting license sales are a major revenue source. Deer hunting, breeding, and tourism is estimated to add billions of dollars to some state economies. Since states are generally allowed to charge higher prices for hunting licenses to nonresidents, these sales can be a significant source of revenue. Each state implements a unique management strategy and faces a geographically dispersed set of challenges. Table 2 reports variables of interest for the decision support system, factors under study or reported as issues of concern by state deer managers or conservation groups. 


\section{Issues in Information Systems}

Volume 15, Issue II, pp. 77-88, 2014

Table 2. Variables of Interest: Reported Factors Related to Decline of Deer Populations

\begin{tabular}{|l|l|l|l|l|}
\hline State & Issue & & State & Issue \\
\cline { 1 - 1 } & MI & Coyotes, overhunting, sever winter, EHD \\
\hline CT & Habitat loss and fragmentation, lions & Predation. First decline since early 1900's & NC & Coyote, mature forests \\
\hline CO & Habitat, EHD (disease), energy development & ND & Drought, EHD, Habitat, energy development \\
\hline FL & Flood, pythons & MT & Habitat, severe winter, Predation \\
\hline GA & Coyotes, new to the region & SC & Coyote \\
\hline IL & Overhunting, drought, & OR & Habitat, disease, population model \\
\hline IA & Overhunting, drought, EHD & WY & Oil and gas development \\
\hline MN & Habitat, coyote, sever winter, EHD & WV & Aging Forests \\
\hline
\end{tabular}

Competitor profiling, a common strategic management technique discussed at length by Michael Porter [18], provides the framework for Table 3 that summarizes current deer management practices and issues for each state. 
Table 3. Results of Environmental Scanning for Deer Management Explanation of Table Column Headings: Goal: Management Strategy for Population, Up, Down, or Stable. \% Peak: Current deer harvest as a percent of peak harvest. Peak Year: Year of Peak Deer Harvest. Hunter Success $^{A}$ : Percent success, a measure of hunting pressure. Buck to Doe: Buck Harvest Relative to Doe Harvest: Less is less bucks than does, Balanced is approximately balanced, More is 60 to 80 percent Bucks, Most is 81 to 95 percent bucks, Only is all or almost all bucks

\begin{tabular}{|c|c|c|c|c|c|c|}
\hline State & Goal & $\begin{array}{c}\% \\
\text { Peak }\end{array}$ & $\begin{array}{l}\text { Peak } \\
\text { Year }\end{array}$ & $\begin{array}{l}\text { Hunter } \\
\text { Success }\end{array}$ & $\begin{array}{l}\text { Buck } \\
\text { to Doe }\end{array}$ & Other Issues \\
\hline $\mathbf{A L}$ & Up & 53 & 2000 & $80-90$ & Balanced & Coyote predation reduced the herd recently. \\
\hline $\mathbf{A K}$ & Up & Stable & - & 23 & More & Nearly stable population fluctuates with harsh winter \\
\hline $\mathbf{A Z}$ & Up & 37 & 1961 & 25 & Only & $\begin{array}{l}\text { About } 12 \text { percent doe historically, buck only since } \\
1991\end{array}$ \\
\hline $\mathbf{A R}$ & Stable & 100 & 2012 & 70 & Balanced & Also seeks to balance buck age distribution. \\
\hline CA & Up & 13.8 & 1956 & $8-17$ & Only & $\begin{array}{l}\text { Average } 3 \text { percent doe harvest since } 1927 \text {, most } \\
\text { extreme of any state }\end{array}$ \\
\hline $\mathbf{C O}$ & $\mathrm{Up}$ & $33-50$ & $1940 \mathrm{~s}$ & 44 & More & Limited historical data, energy development concerns. \\
\hline CT & Down & 75 & 2012 & 24.7 & Balanced & $\begin{array}{l}\text { Seeks to balance buck age distribution. Reported } \\
\text { hunter success rate }\end{array}$ \\
\hline DE & Stable & 97 & 2004 & 73 & Balanced & Seeks to balance buck age distribution \\
\hline FL & Stable & 100 & 2012 & 100 & Balanced & About one deer harvested for every hunt. \\
\hline GA & Up & 86 & 2004 & 140 & Balanced & A leader in balanced demographics, coyote predation \\
\hline HI & Down & 100 & 2013 & & Balanced & Hawaii eradicating a few nonnative deer. Limited data \\
\hline ID & Up & 52 & 1989 & 100 & Balanced & Balanced age and sex except a few years in 1970s \\
\hline IL & Up & 74 & 2005 & 45 & Balanced & Goal was down for a decade until this year \\
\hline IN & Down & 92 & 2012 & 68 & Balanced & Recent harvest declines may signal a goal change \\
\hline IA & Down & 47 & 2005 & 33 & Balanced & Pressure to change goal to up \\
\hline KS & Up & 85 & 2000 & 48 & Balanced & Concerns about drought and disease, EHD \\
\hline KY & Stable & 100 & 2012 & 77 & Balanced & Trying to maintain balance while hunters want bucks \\
\hline $\mathbf{L A}$ & Up & 58 & 1999 & 75 & Balanced & Data based on survey. Coyotes and hogs reduced herd \\
\hline ME & Up & 50 & 1958 & 53 & More & Maine struggling grow herd, harsh winter, habitat loss \\
\hline MD & Down & 95 & 2009 & 45 & Less & Stable population but some counties down 60 percent \\
\hline MA & Stable & 92 & 2002 & 20 & More & Significant bow hunting, deer decline in west of state \\
\hline MI & Up & 69 & 1999 & 46 & More & Harsh winters. Antler point restrictions \\
\hline MN & Up & 64 & 2003 & 35 & Balanced & Harsh winters, goals have changed over 10 years \\
\hline MS & Stable & 85 & 2010 & 115 & Balanced & 1.15 deer per hunter. Floods, land use, coyotes, swine \\
\hline MO & Up & 78 & 2006 & 50 & Balanced & Goal change in 2013 after 10 years of down \\
\hline
\end{tabular}


Table 3 (continued). Results of Environmental Scanning for Deer Management Explanation of Table Column Headings: Goal: Management Strategy for Population, Up, Down, or Stable. \% Peak: Current deer harvest as a percent of peak harvest. Peak Year: Year of Peak Deer Harvest. Hunter Success $^{A}$ : A measure of hunting pressure. Buck to Doe: Buck Harvest Relative to Doe Harvest: Less is less bucks than does, Balanced is approximately balanced, More is 60 to 80 percent Bucks, Most is 81 to 95 percent bucks, Only is all or almost all bucks

\begin{tabular}{|c|c|c|c|c|c|c|}
\hline State & Goal & $\begin{array}{c}\% \\
\text { Peak }\end{array}$ & $\begin{array}{l}\text { Peak } \\
\text { Year }\end{array}$ & $\begin{array}{c}\text { Hunter } \\
\text { Success } \\
\%\end{array}$ & $\begin{array}{l}\text { Buck } \\
\text { to Doe }\end{array}$ & Other Issues \\
\hline MT & Up & 64 & 2006 & 21 & Balanced & Mule deer populations down 55\% from 2007 \\
\hline NE & Up & 60 & 2011 & 50 & Balanced & $\begin{array}{l}\text { Recent drought and EHD. Doe protection for mule } \\
\text { deer. }\end{array}$ \\
\hline $\mathbf{N V}$ & Up & 35 & 1988 & 41 & Most & Bucks 90 percent of harvest. \\
\hline NH & Up & 88 & 1968 & & More & Bucks 65 percent of harvest \\
\hline $\mathbf{N J}$ & Down & 67 & 2000 & 63 & Less & About half the deer are killed by hunting each year \\
\hline NM & Up & 27 & $1960 \mathrm{~s}$ & 45 & Only & $\begin{array}{l}\text { Buck only } 1899 \text { to } 1931 \text { and since } 1983 \text {. Bucks must be } \\
\text { fork antlered. Peak based on population estimates. }\end{array}$ \\
\hline NY & Down & 79 & 2002 & 35 & Balanced & $\begin{array}{l}\text { Harvest } 56 \% \text { bucks. Reducing harvest of young bucks. } \\
\text { Success rate is deer kill divided by total hunters. }\end{array}$ \\
\hline NC & Stable & 100 & 2013 & 90 & Balanced & Cherokee Indians having to restock tribal lands \\
\hline ND & Up & 32 & 2006 & 55 & More & Harsh winters, habitat loss, EHD. Permits reduced. \\
\hline $\mathbf{O H}$ & Down & 81 & 2006 & 33 & Less & Reducing harvest of young bucks to balance ages \\
\hline OK & Stable & 90 & 2006 & 69 & Balanced & Also balances age distribution \\
\hline OR & Up & 26 & 1961 & 26 & Most & $\begin{array}{l}\text { Doe harvest } 7.6 \text { percent, } 4 \text { percent for mule deer. } \\
\text { Minimum target of } 12 \text { bucks per hundred does. }{ }^{15}\end{array}$ \\
\hline PA & Up & 68 & 2002 & 37 & Balanced & Reduced doe tags in 2014. Antler restrictions. \\
\hline RI & Down & 80 & 2008 & 26 & Balanced & Using hunting pressure to reduce herd \\
\hline SC & Stable & 70 & 2002 & 90 & Balanced & Habitat change and coyotes predation pressure herds \\
\hline SD & Up & 75 & 2010 & 44 & Balanced & Change in goal from die off related to EHD \\
\hline TN & Stable & 69 & 1999 & 83 & Balanced & Change in goal to up under consideration \\
\hline TX & Stable & 87 & 2010 & 60 & Balanced & Pioneers in advocating for balanced herd demographics \\
\hline UT & Up & 22 & 1961 & 37 & Most & $\begin{array}{l}\text { Utah switched to buck only harvest in } 1975 \text { except in } \\
\text { population control areas where does are also targeted }\end{array}$ \\
\hline VT & Up & 54 & 1980 & 84 & More & $\begin{array}{l}\text { Often uses balanced population, current goal is up. } \\
\text { Use antler restrictions to balance buck age distribution. }\end{array}$ \\
\hline VA & Stable & 94 & 2009 & 80 & Balanced & Population on target for past 10 years. \\
\hline WA & Stable & 65 & 1979 & 28 & More & $\begin{array}{l}\text { Bucks about } 80 \text { percent, down from about } 88 \text { percent in } \\
\text { 1998. White-tailed antler restrictions since } 1991 \text {. Peak } \\
\% \text { estimate approximate. }\end{array}$ \\
\hline WV & Down & 59 & 2002 & 45 & Balanced & Rebuilding herd in some areas. Goal may change. \\
\hline WI & Down & 60 & 2000 & 45 & Less & $\begin{array}{l}\text { Goal may change to up after severe winter, } 35 \% \\
\text { success rate for archery }\end{array}$ \\
\hline $\mathbf{W Y}$ & Stable & 65 & 1970 & 68 & More & $\begin{array}{l}\text { Stable population over past } 10 \text { years. Bucks } 71 \text { percent } \\
\text { of total. Mule deer half of peak. \%Peak approximate }\end{array}$ \\
\hline
\end{tabular}

One of several problems associated with the hunter success rate as a model variable is that some states calculate based on reported data while others do surveys. The 8 percent success rate for California from Table 3 is reported data; the 19 percent rate is from surveys. Estimated data is typically about twice or more the reported data. In Connecticut, the reported number is somewhat low also in part because most hunters use bows which tend to reduce success rates. 
As reported in Table 4, although there have been calls for moderating the deer population in the press, half of the states are currently employing a deer strategy designed to increase deer populations. Only 11 states, 22 percent, are trying to reduce populations and two of those states seem likely to change to an up or stable strategy in the next year.

Table 4. Summary of Table 3, State Deer Strategies

\begin{tabular}{|c|c|c|c|c|c|}
\hline Goal & Up & Down & Stable & & \\
\hline Percent of Total & 50 & 22 & 28 & & \\
\hline Buck to Doe & Less & Balanced & More & Most & Only \\
\hline Percent of Total & 8 & 60 & 20 & 6 & 6 \\
\hline
\end{tabular}

The modern deer management concept of maintaining balanced herd demographics to support herd health is commonly thought to have emerged in Texas during the 1940s and spread throughout the Southeast and then into other states in the east. Far western states have been the last to adopt this approach. Four of the eleven states currently attempting to reduce their deer population are following the "less strategy", harvesting less bucks than does, one method of lowering population. Most states, 60 percent, are following a balanced strategy even though seven of these states have a goal of reducing the deer population. Only three states -- Arizona, California, and New Mexico - are following the buck only harvest strategy that was used by many states in the early to mid-1900's when the goal was to restore deer populations. Of these states, California has pursued this strategy much longer than any other state with an average doe harvest of less than 3 percent since 1927 and with only one year having a deer harvest that would place it in the "Most" strategy. Arizona has been bucks only since 1991 and New Mexico since 1983; however, New Mexico has placed restrictions preventing the taking of too many young bucks to help balance age distributions.

California is currently conducting research into what environmental factors are responsible for the decline of its deer herd. As Table 5 reveals, California has put more hunting pressure on its herd than any other state, as measured by hunter success. It has also maintained skewed demographics using a bucks only harvest for much longer than any other state and it has a relatively low proportion of mature bucks in the herd. A recent study from Spain supports previous studies that conclude a management strategy relying on skewed herd demographics is not sustainable [25]. These results suggest that herd management is a contributing factor to the decline of California deer and indicate further investigation is warranted. North Dakota's severe decline is recent, attributed to several harsh winters and some aggressive hunting pressure that has been recently reduced.

Table 5. States With Lowest Percent of Peak Harvest

\begin{tabular}{|l|l|l|l|l|}
\hline State & $\begin{array}{l}\text { \% } \\
\text { Peak }\end{array}$ & $\begin{array}{l}\text { Peak } \\
\text { Year }\end{array}$ & $\begin{array}{l}\text { Hunter } \\
\text { Success } \\
\%\end{array}$ & $\begin{array}{l}\text { Buck } \\
\text { to Doe }\end{array}$ \\
\hline CA & 13.8 & 1956 & $8-17$ & Only \\
\hline UT & 22 & 1961 & 37 & Most \\
\hline OR & 26 & 1961 & 36 & Most \\
\hline NM & 27 & $1960 \mathrm{~s}$ & 45 & Only* \\
\hline ND & 32 & 2006 & 55 & More \\
\hline NV & 35 & 1988 & 41 & Most \\
\hline * NM relies on antler restrictions \\
\hline
\end{tabular}

It is well known that at too low a level of the buck to doe ratio, the population becomes unsustainable because there are simply not enough bucks to impregnate available does. California relies on very rough estimates of regional buck to doe ratios in its management information system. In one case, for example, a detailed survey reported that only three percent of the herd was actually bucks [22]. Not enough to sustain a herd. Poor data about herd status may be another contributing factor to the population decline. 


\section{Issues in Information Systems}

Volume 15, Issue II, pp. 77-88, 2014

Geographic information among deer in herds is passed on through elders. Fewer elders make it more difficult for herd groups to retain the information, a disruption of the herd information system. Wildlife managers throughout the west are investigating the cause of the mule deer and black-tailed decline. This information problem presents an interesting hypothesis. Until recently, managers in Wyoming were unaware that the mule deer take an annual 150 mile migration, requiring much geographical information. The problem of harvesting too many elders to lead the group has recently been demonstrated for tuna [7]. The authors suggest their findings can likely be extrapolated to other animal species, although we find no evidence that this issue is being investigated as a cause for the decline of mule deer herds. The mule deer herds in the western Sierra of California have been decimated, although habitat fragmentation and degradation are two known causes contributing to the decline. Buck to doe ratios there are also very low and there are relatively few mature bucks.

Answer to $Q_{3}$ : The pattern of change for U.S. deer populations varies widely among the states and regions. Half the states are trying to increase their populations but face ecological constraints related to habitat, weather, and predation. Management practices resulting in skewed herd demographics may be contributing to the severe drop in the population of California deer. Aggressive hunting pressure appears to be a likely contributing factor, explaining why deer numbers in California have fallen so much more than in neighboring states. Predation, habitat loss and degradation, disease, and severe weather are all factors affecting deer populations.

\section{CONCLUSIONS}

With regard to the three general questions raised by examining the public debate over deer management, the information indicates that since 2006 the deer harvest data is trending lower, suggesting that the U.S. population is trending down toward the bottom of the range estimated for pre-European levels of around the year 1500 . The California deer population estimate shows a significant rise and fall over the past 100 years, putting current populations near levels where deer hunting was suspended to preserve the herd in the early 1900's and representing the most dramatic decline of any state over this time period.

A difference between California and other states evident in the state profiles is the significant hunting pressure in California, measured by hunting success. Also a persistent policy of hunting bucks only that skews population demographics may be contributing to the decline of the herd. Although there is a wide perception in the press about abundant deer populations, the herd size in many western states is significantly below the peak. Only 11 states have a policy to reduce the deer population. One of those states is New York, the geographic origination for two of the media reports about deer overpopulation. Many media reports generalize about deer populations when deer herd status varies dramatically by region.

In addition to data, the environmental scanning has provided context and ideas for future research. A dissertation published just as this article was undergoing final revision attempts to take a similar approach in using data from several states to conduct an analysis, the author comments that having “... detailed data ... for the majority of the states would enable white-tailed deer managers in every state to quickly interpret the data and make conclusions about what is occurring in other states, benefiting the deer manager in many ways [3]." Many public and private decision making processes could benefit from this kind of easy access to data and analysis.

\section{REFERENCES}

1. Abebe, M., Angriawan, A., \& Tran, H. (2010). Chief executive external network ties and environmental scanning activities: An empirical examination. Strategic Management Review 4.1 (2010): 30-43.

2. Babatunde, B. O., \& Adebisi, A. O. (2012). Strategic environmental scanning and organization performance in a competitive business environment. Economic Insights-Trends \& Challenges, 64(1), 24.

3. Cain, R. Lynn. (2014). "A Quantitative Analysis of White-Tailed Deer Harvest Across States and Counties" (2014). Scholar Commons, Theses and Dissertations. Paper 2645. p. 107. Available: http://scholarcommons.sc.edu/etd/2645

4. Cambronne, A. (2014). Can't see the forest for the deer. The Wall Street Journal. March 11.

5. Choo, C. W. (2002). Information management for the intelligent organization: the art of scanning the environment. Information Today, Inc., p. 7

6. Davis, C. (2000). U.F. Research: Does make up for losses of hunted bucks. University of Florida News, 


\section{Issues in Information Systems}

Volume 15, Issue II, pp. 77-88, 2014

November 16. Available: http://news.ufl.edu/2000/11/16/deer/

7. De Luca, G., Mariani, P., MacKenzie, B.R., Marsili. M., (2014). Fishing out collective memory of migratory schools. Journal of The Royal Society Interface. 11 (95): 20140043 DOI: 10.1098/rsif.2014.0043

8. Drehle, D.V. (2013). America's pest problem: it's time to cull the herd. Time Magazine. December 9. p. 38.

9. Fabbe-Costes, N., Roussat, C., \& Colin, J. (2011). Future sustainable supply chains: what should companies scan? International Journal of Physical Distribution \& Logistics Management. 41(3), 228

10. Frye, B. (2006). Deer wars: science, tradition, and battle over managing whitetails in Pennsylvania. Keystone Books.

11. Hldaky, G.B. (2014). Helicopter surveys, deer, and lyme disease in connecticut. Hartford Courant. March 18 available: http://courantblogs.com/capitol-watch/helicopter-surveys-deer-and-lyme-disease-in-connecticut/

12. Longhurst, W.M., Leopold, A.S., Dasmann, R.F., (1952) A survey of California deer herds: their ranges and management problems. California Department of Fish and Game, Bureau of Game Commission, Game Bulletin, No. 6. p. 30

13. Martinez-Jauregui, M., \& Hernuzo, A.C. (2014). A note on the effectiveness of incorporating management objectives with ecological variables when modeling red deer abundance. European Journal of Wildlife Research. April, p. 1

14. Mayer, J.H., Steinecke, N., \& Quick, R (2011). Improving the applicability of environmental scanning systems: state of the art and future research. Governance and Sustainability in Information Systems. Managing the Transfer and Diffusion of IT. Springer Berlin Heidelberg. 207-223.

15. McCabe, R.E. \& McCabe, T.R. (1984). Of Slings and Arrows: An Historical Retrospection, in White-tailed Deer Ecology and Management. A Wildlife Management Institute Book. p. 60

16. Oregon Department of Fish and Wildlife (2003). Oregon's Mule Deer Management Plan available: http://soda.sou.edu/awdata/040726f1.pdf p. 8

17. Palomino, M. A., Taylor, T., \& Owen, R., (2013). Evaluating business intelligence gathering techniques for horizon scanning applications. Advances in Soft Computing and Its Applications. Springer Berlin Heidelberg, 2013. 350-361.

18. Porter, M. E. (1983). Cases in competitive strategy. Simon and Schuster.

19. Ranjit B. (2008). Competitive intelligence process and tools for intelligence analysis. Industrial Management \& Data Systems. 108(4), $510-528$

20. Rohrbeck, R. \& Bade, R. (2012). Environmental scanning, futures research, strategic foresight and organizational future orientation: a review, integration, and future research directions. ISPIM Annual Conference, Barcelona, Spain p. 14

21. Russell, F., Zippin, D. B., \& Fowler, N. L. (2001). Effects of white-tailed deer (odocoileus virginianus) on plants, plant populations and communities: a review. American Midland Naturalist. 146(1), 2.

22. Smith, D. (2014). Studies planned to monitor Siskiyou deer herds. Siskiyou Daily News. April 4. Available: http://www.siskiyoudaily.com/article/20140404/NEWS/140409800

23. Sprague, R. (1980). "A Framework for the Development of Decision Support Systems.” MIS Quarterly. 4(4), 1

24. Stienstra, T. (2013). California deer face more challenges than ever. SFGate. September 21. Available: http://www.sfgate.com/outdoors/article/California-deer-face-more-challenges-than-ever-4833244.php

25. Torres-Porras, J., Carranza, J., Perez-Gonzalez, J., Mateos, C., Alarcos, S. (2014). The tragedy of the commons: unsustainable population structure of Iberian red deer in hunting estates. European Journal of Wildlife Research. 60(2), 351-357.

26. VerCauteren, K. (2003). The Deer Boom: Discussins on Population Growth and Range Expansion of the WhiteTailed Deer. USDA National Wildlife Research Center - Staff Publications. p. 16

27. Webb, G.K. (2013). Deer herd management using the internet: a comparative study of California targeted by data mining the internet. Issues in Information Systems. 14(2), 156-165

28. Wei, C. \& Lee, Y. (2004). Event detection from online news documents for supporting environmental scanning. Decision Support Systems. 36(4), 385-401.

29. Welter, S., Mayer, J.H., and \& Quick, R. (2013). Improving environmental scanning systems using Bayesian networks. BuR-Business Research 6.2: 196-213. 